\title{
EFFECT OF BIOGAS ENRICHED WITH HYDROGEN ON THE OPERATION AND PERFORMANCE OF A DIESEL-BIOGAS DUAL ENGINE
}

\author{
EFECTO DEL BIOGÁS ENRIQUECIDO CON HIDRÓGENO EN LA OPERACIÓN \\ Y RENDIMIENTO DE UN MOTOR DUAL DIÉSEL-BIOGÁS
}

\author{
Juan-Pablo Gómez-Montoya $^{1 *}$, Karen-Paola Cacua-Madero ${ }^{1}$, Layrisser Iral-Galeano ${ }^{1}$ and \\ Andrés-Adolfo Amell-Arrieta ${ }^{1}$ \\ 'Grupo de Ciencia y Tecnología del Gas y Uso Racional de la Energía (GASURE), \\ Universidad de Antioquia, Medellín, Antioquia, Colombia \\ e-mail: juan.gomez46@udea.edu.co
}

(Received: Jul. 11, 2012; Accepted: Dec. 14, 2012)

\section{ABSTRACT}

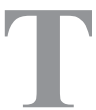

he effect of hydrogen enrichment was tested for a diesel-biogas dual fuel engine. The operation and performance characteristics, such as thermal efficiency, pollutant emissions and combustion parameters were determined. Experiments have been carried with a stationary compression ignition $(\mathrm{Cl})$ engine coupled with a generator in dual mode using a typical biogas composition of $60 \%$ vol. $\mathrm{CH}_{4}$ and $40 \%$ vol. $\mathrm{CO}_{2}$. For every load engine evaluated, the hydrogen concentration was varied from 5 to $20 \% \mathrm{H}_{2} \mathrm{v} / \mathrm{v}$. The results showed increases in peak pressure chamber up to 10.7 bar, and diesel substitution levels up to $80 \%$ under conditions of steady combustion without knocking. Also, thermal efficiency increases up to $16 \%$ and carbon monoxide emissions decreases up to $13 \%$ at full load, and $20 \%$ of hydrogen in engines operating in diesel-biogas dual mode.

Keywords: Diesel dual engines, Biogas, Enrichment with hydrogen, Contaminant emissions, Thermal efficiency.

How to cite: Gómez-Montoya, J. P., Cacua-Madero, K. P., Iral-Galeano, L. \& Amell-Arrieta, A. (2013). Effect of biogasenriched with hydrogen on the operation and performance of a diesel-biogas dual engine. CT\&F - Ciencia, Tecnología y Futuro, 5(2), $61-72$.

${ }^{*}$ To whom correspondence should be addressed

+V Congreso Internacional de Ciencia y Tecnología de los Biocombustibles, CIBSCOL 2012, Universidad Industrial de Santander, Bucaramanga, Santander, Colombia. 5 - 8 de junio de 2012. 


\section{RESUMEN}

E

I efecto del enriquecimiento con hidrógeno fue probado en un motor dual diesel-biogás. Las características de operación y rendimiento, tales como eficiencia térmica, emisiones contaminantes y parámetros de combustión fueron determinados. Los experimentos se llevaron a cabo en un motor estacionario de ignición por compresión (Cl) acoplado con un generador en modo dual utilizando un biogás con una composición típica de $60 \%$ vol. $\mathrm{CH}_{4}$ y $40 \%$ vol. $\mathrm{CO}_{2}$. Para cada grado de carga evaluado, la concentración de hidrógeno fue variada desde 5 a $20 \% \mathrm{H}_{2} \mathrm{v} / \mathrm{v}$. Los resultados mostraron incrementos en la presión máxima en la cámara de combustión de hasta 10.7 bar y en los niveles de sustitución de diesel de hasta $80 \%$ bajo condiciones de combustión estable sin golpeteo, así como también incrementos en la eficiencia térmica de hasta $16 \%$. Así mismo, se presentaron disminuciones en las emisiones de monóxido de carbono de hasta $13 \%$ para las condiciones de carga plena y $20 \%$ de hidrógeno con respecto al motor operando en modo dual diesel-biogás.

Palabras clave: Motores diésel duales, Biogás, Enriquecimiento con hidrógeno, Emisiones contaminantes, Eficiencia térmica.

\section{RESUMO}

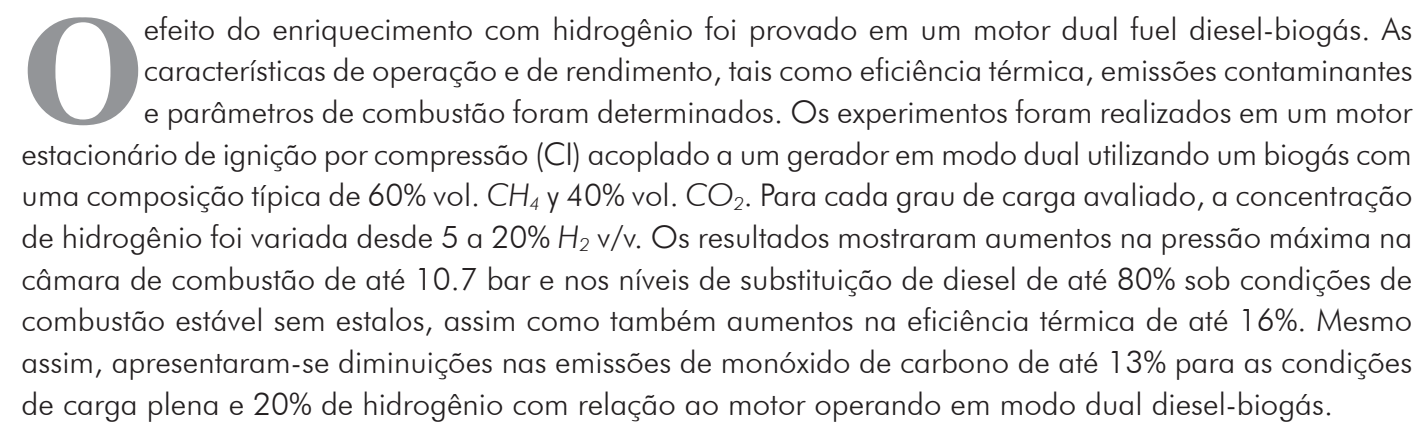

Palavras-chave: Motores a diesel duais, Biogás, Enriquecimento com hidrogênio, Emissões contaminantes, Eficiência térmica. 


\section{INTRODUCTION}

The introduction of alternative fuels during the last two decades has raised the need for research in energy production technologies in order to maximize its use. Diesel engines have been in the market for over 100 years and have had a number of adaptations, including the use in the dual mode conversion with gaseous fuels to reduce fossil fuel consumption (Abd Alla, Soliman, Badr \& AbdRabbo, 2000; Bedoya, Amell, Cadavid \& Pareja, 2007; Bilcan, Tazerout, Le Corre \& Ramesh, 2001).

Researches about biogas and its use for generation of thermal energy, illumination, heating and electricity generation have increased in the last decades. However, these have not been significantly implemented, due to the problems that biogas presents: its lower heating value, low flame speed, high percentages of inert gases and presence of sulfur. Engines exclusive for biogas have a high economic cost, and they are not commercially available for powers smaller than $100 \mathrm{~kW}$. As a result, -and with no dependence on diesel fuel- the use of biogas in diesel dual mode becomes difficult (Porpatham, Ramesh \& Nagalingam, 2008; Henham \& Makkar, 1998).

A dual engine is a diesel engine operating on gaseous fuel generally at low heating value. The modification is simple and involves introducing the gaseous fuel with the air at admission, maintaining a small amount of diesel fuel for ignition as pilot fuel. Biogas is a fuel with low heating value used widely in dual engines to produce electricity and heat in remote places, such as industries, agro-industry and landfills with availability of raw material from organic origin for anaerobic decomposition and production of this energy.

The operation of diesel engines with this kind of fuel decreases both thermal efficiency and emissions of methane, particularly at partial load (Abd Alla, Soliman, Badr \& Abd Rabbo, 2001; Balasubramanian, Sridhara \& Ganesan, 1995; Bedoya, Amell \& Cadavid, 2009; Duc \& Wattanavichien, 2007; Liu \& Karim, 2009; Korakianitis, Namasivayam \& Crookes, 2011). In this study we determined the effect of hydrogen in a diesel-biogas dual engine working at its maximum rate of substitution.
Tests were conducted in an engine at a constant speed of $1500 \mathrm{rpm}$. This can be described as a single cylinder constant speed spark ignition engine at different hydrogen levels, with mixtures of different equivalence ratios. Hydrogen was added and tested in small amounts (5, 10 and $15 \%$ on the energy basis) to biogas. Hydrogen significantly enhances the combustion rate and extends the lean limit of combustion of biogas. There is an improvement in brake thermal efficiency and brake power. However, beyond $15 \%$ hydrogen has the need to retard the ignition timing to control knock. Significant reductions in hydrocarbon levels were observed. There was no increase in nitric oxide emissions due to the use of retarded ignition timing and the presence of carbon dioxide. Peak pressures and heat release rates are lower with hydrogen addition, since the ignition timing is retarded to avoid knock. There is a reduction in cycle-by-cycle variations in combustion with lean mixtures. In general, the $10 \%$ hydrogen addition was found to be the most suitable (Porpatham, Ramesh \& Nagalingam, 2007).

In Colombia, the Ciencia y Tecnología del Gas y Uso Racional de la Energía (GASURE) research group has carried out research in diesel-biogas dual engines to increase their use, through the characterization of engines and the application of mitigation techniques to decrease the negative effects due to biogas presence in combustion process inside them. It is important to note that biogas is a gaseous fuel with a high content of inert gases, a lower heating value and low burning velocity. The mitigation techniques implemented by GASURE were overload and enrichment of air with oxygen. This research found increases in diesel fuel substitution percentage by biogas, as well as increases in thermal efficiency and decreased pollutant emissions to partial load. (Bedoya et al., 2009).

In regards to diesel engines operating with liquefied petroleum gas and hydrogen mixtures, other researchers have found increases in the peak pressure -due to hydrogen presence- and improvements in thermal efficiency -due to the higher mixture reactivity and increased burning velocity of the mixture by hydrogen presence- (Lata \& Misra, 2010).

Our investigation proposed the use of a diesel engine operating in dual mode; diesel plus mixtures of biogas 
with hydrogen addition, with the intention of increasing the thermal brake efficiency and the substitution level due to the presence of the hydrogen. As a result, biogas could be used in a better way (renewable fuel) and diminish the use of diesel fuel (nonrenewable fuel).

\section{EXPERIMENTAL DEVELOPMENT}

\section{Setup}

The experimental work was performed in Medellín, Colombia, a city located at 1500 meters above sea level, where environmental conditions are $25^{\circ} \mathrm{C}$ and 0.853 bar. For the experiments we used a two-cylinder diesel engine for stationary applications coupled to an electric generator to produce electricity. Table 1 shows engine technical specifications and some characteristics of stationary mode operation. The engine load was simulated by a variable electrical resistance bank connected to the electric generator with loads of 3 (35), 4 (47), 6 (70) and $8.5 \mathrm{~kW}(100 \%)$, and the power output was dissipated as heat to the environment. The flow rate of $\mathrm{CH}_{4}, \mathrm{CO}_{2}$ and hydrogen were measured with rotameters and the flow rate of air was measured with an orifice meter and a U-tube manometer. Exhaust emissions were measured with a gas analyzer that uses an infrared sensor for measurements of $\mathrm{CH}_{4}, \mathrm{CO}_{2}$ and $\mathrm{CO}$ and a paramagnetic sensor to $\mathrm{O}_{2}$.

A piezoelectric transducer (Kistler; model: 6125B) was flush mounted in the cylinder head and the incylinder pressure was measured. A piezoresistive transducer was installed at admission duct to capture air pressure at inlet. To measure the crank angle position, a precision shaft encoder (Kistler: model: 2614A) with a resolution of 3600 pulses per revolution and a resolution of $0.1^{\circ}$ was used. The signals were captured using a National Instruments ${ }^{\circledR}$ data acquisition board of $250 \mathrm{kHz}$ and 16 bits resolution. Figure 1 shows experimental facility schematic diagram.

\section{Experimental Procedure}

The experimental work started with preliminary investigation of the engine running on neat diesel fuel, in order to determine its performance characteristics. Elec- tric power outputs at 40,50, 70 and $100 \%$ of full load were obtained. Engine loads were set from 3 to $10 \mathrm{~kW}$.

Table 1. Test engine characteristics.

\begin{tabular}{|l|l|}
\hline \multicolumn{1}{|c}{ Type } & $\begin{array}{c}\text { Lister Petter TR2, DI, four stroke, two } \\
\text { cylinders, naturally aspirated, air cooled }\end{array}$ \\
\hline Displacement & $1.55 \times 10^{-3} \mathrm{~m}^{3}$ \\
\hline Bore x stroke & $0.098 \mathrm{~m} \times 0.115 \mathrm{~m}$ \\
\hline Compression ratio & $15.5: 1$ \\
\hline Rated power & $20 \mathrm{~kW}$ at $3000 \mathrm{rpm}$ \\
\hline Maximum torque & $76 \mathrm{Nm}$ at $1800 \mathrm{rpm}$ \\
\hline Inlet valve open & $36^{\circ} \mathrm{BTDC}$ (Before Top Dead Center) \\
\hline Exhaust valve close & $32^{\circ} \mathrm{BTDC}$ \\
\hline
\end{tabular}

The maximum substitution levels in dual fuel mode were found for each load. In the first stage of the experimental phase, we determined the maximum value of biogas that could be used in the engine without shutting down or reaching severe deterioration of combustion stability. To find the maximum substitution level, the stability principle was used, which consists on a constant monitor of the pressure curve vs. crankshaft rotation angle, in order to detect incorrect operating cycles and knocking, which are a consequence of the gaseous fuel presence.

Substitution level $(\mathrm{Z})$ was determined using diesel fuel mass flow in diesel mode $\dot{m}_{D}(\mathrm{~kg} / \mathrm{s})$ and biogas mass flow in dual mode $\dot{m}_{D}(\mathrm{~kg} / \mathrm{s})$ according to Equation 1:

$Z=\frac{\dot{m}_{D}-\dot{m}_{b}}{\dot{m}_{D}} \cdot 100(\%)$

In the second experimental phase, four levels of hydrogen $(5,10,15$ and $20 \% \mathrm{v} / \mathrm{v}$ biogas volumetric base) were added; this was done when conditions where the maximum substitution level in dual fuel mode with biogas were obtained. The substitution level $(Z)$ was determined using diesel fuel mass flow in diesel mode $\dot{m}_{D}(\mathrm{~kg} / \mathrm{s})$ and biogas-hydrogen mass flow in dual mode $\dot{m}_{D}(\mathrm{~kg} / \mathrm{s})$ according to Equation 2:

$Z=\frac{\dot{m}_{D}-\dot{m}_{b h}}{\dot{m}_{D}} .100(\%)$ 


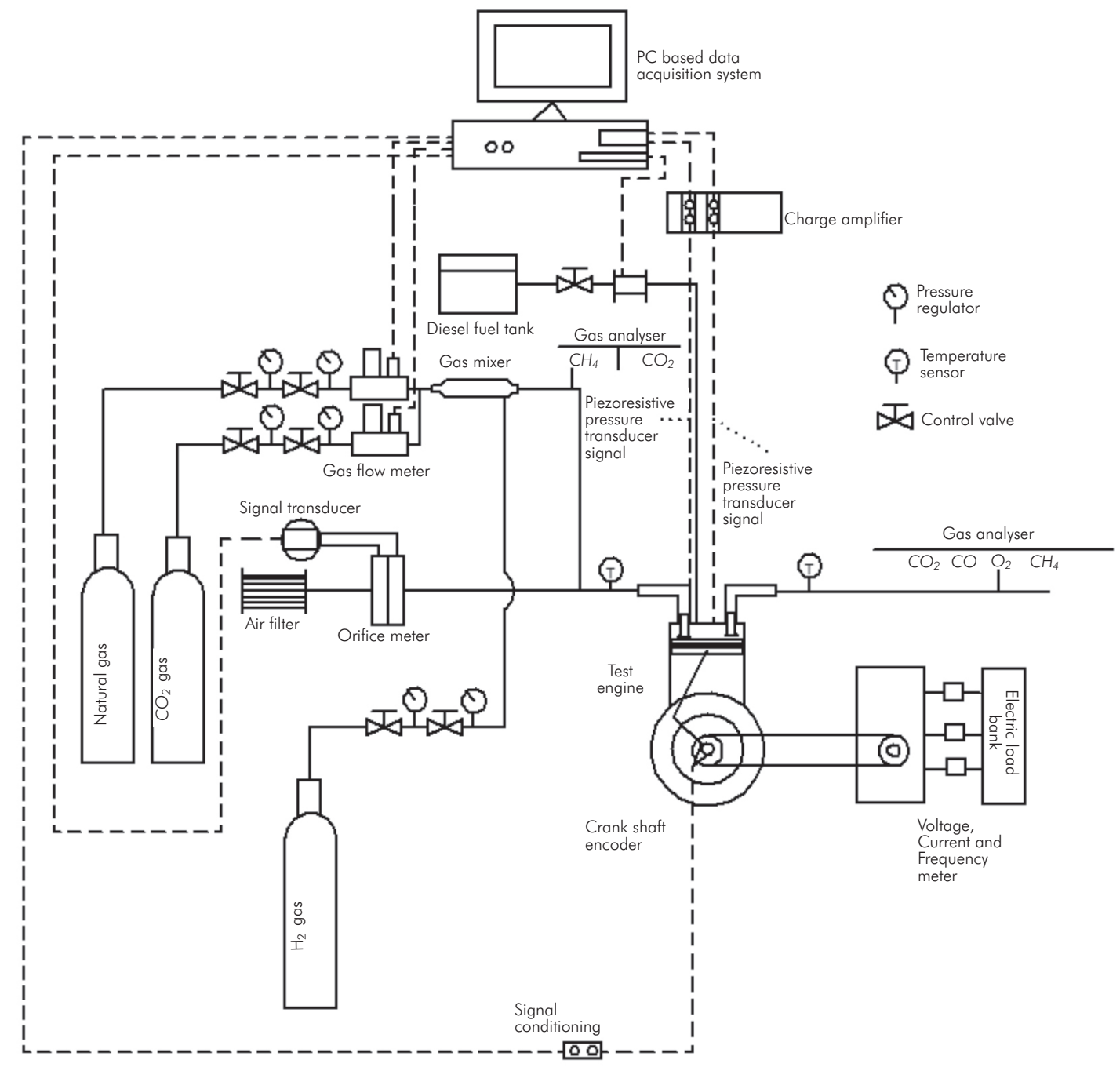

Figure 1. Schematic diagram of the experimental setup.

Experimental factorial design was used to study trends in performance parameters and engine combustion; three replicates were made for each experiment. The engine performance was evaluated by comparing thermal efficiency, $\mathrm{CO}$ and $\mathrm{CH}_{4}$ emissions and cylinder pressure traces.

The thermal efficiency $\left(\eta_{E}\right)$ was defined as the ratio of the electrical power output $\left(\boldsymbol{N}_{E}\right)$ and energy supplied by diesel, biogas and hydrogen, according to Equation 3:

$\eta_{E}=\frac{N_{E}}{\dot{m}_{B} P C I_{B}+\dot{m}_{D} P C I_{D}+\dot{m}_{h} P C I_{h}} \cdot 100(\%)$
$N_{E}$ is, according to Equation 4, electrical power output. $V$ is voltage and $I$ is the current of the electrical generator.

$N_{E}=V I \sqrt{3}$

\section{RESULTS AND ANALYSIS}

Figure 2 shows cylinder pressure curves corresponding to $40,50,70$ and $100 \%$ of full load for $20 \% \mathrm{H}_{2}$ in the biogas. The peak pressure was higher for the full load. This is due to the admission of more fuel at the same 
crankshaft rotation angle interval to the same revolutions per minute for all loads. Maximum pressure for full load operation will also lead to a maximum temperature level and heat release, resulting -as discussed below- in a higher thermal efficiency level for operation at full load.

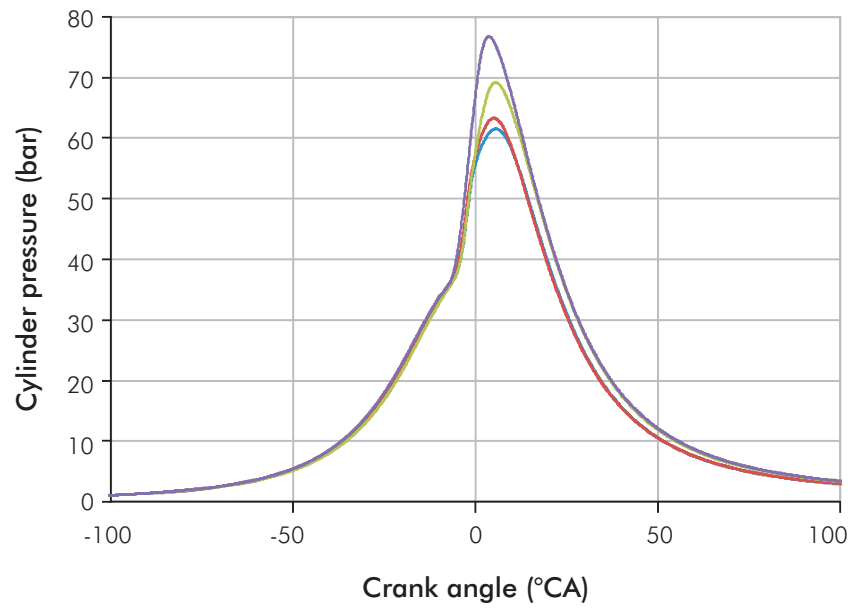

$-40 \%$ load $-50 \%$ load $-70 \%$ load $-100 \%$ load

Figure 2. Cylinder pressure curves vs crank angle position at 40, 50, 70 and $100 \%$ of full load for $20 \%$ hydrogen enrichment.

Figure 3 shows cylinder pressure curves at full load operation for all hydrogen enrichment levels in dual fuel mode. The peak pressure was increased both by the hydrogen enrichment level and the start of pressure rise occurring sooner. The hydrogen presence in the fuel mixture increases the reactivity and the burning velocity. It also impacts the extension of the flammability interval. The presence of hydrogen also increases the combustion stability producing a fast energy release and less heat loss to the walls.

As the pressure increases, the temperature, heat release and thermal efficiency also increases. By adding hydrogen, the combustion process starts faster than diesel-biogas dual mode operation. This allows improving the problems caused by pilot fuel ignition delay, due to the presence of gaseous fuel and inert gases.

When comparing the results in Figures 2 and 3 it is observed that at full load, the hydrogen enriched biogas has a greater influence upon the increase in pressure in the cylinder. The increase in pressure at full load is $17 \%$, due to enriched biogas from 0 to $20 \%$ with hydrogen, compared to a $12 \%$ increase in pressure level when load is $40 \%$, as seen in Figure 4. This figure shows the same tendency as the previous figure for different hydrogen content in the biogas.

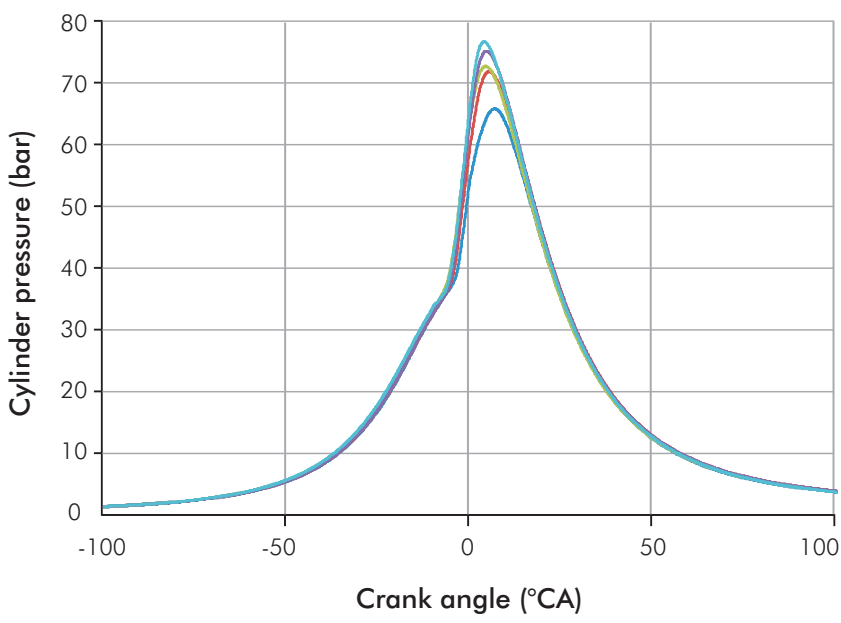

$-0 \% \mathrm{H}_{2}-5 \% \mathrm{H}_{2}-10 \% \mathrm{H}_{2}-15 \% \mathrm{H}_{2}-20 \% \mathrm{H}_{2}$

Figure 3. Cylinder pressure curves vs. crank angle position at full load for each hydrogen enrichment level.

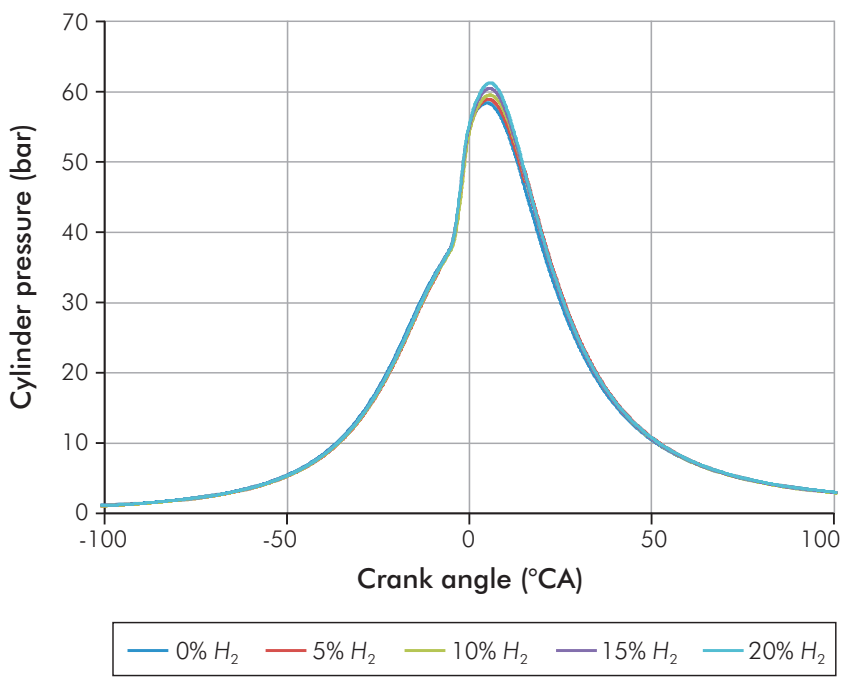

Figure 4. Cylinder pressure traces vs crank angle position at $40 \%$ of full load for each level of hydrogen enrichment.

Figure 5 shows the substitution level, with biogas enriched with hydrogen for all loads. The effect of enriched biogas on substitution percentage is more pronounced at full load, where an increase in hydrogen percentage biogas from 0 to $20 \%$ allows a substitution 
level $12 \%$ higher, becoming almost $80 \%$ of substitution. This is due to more steady combustion by improved combustion properties of the biogas-hydrogen mixture. At $40 \%$ of full load there are not major differences in the substitution level, as a result of the reduction of the equivalence relation to partial loads, which implies a decrease in fuel reactivity. At $70 \%$ of fuel load, diesel substitution level increases only 4 for $20 \% \mathrm{H}_{2} \mathrm{v} / \mathrm{v}$. When operating at $40 \%$ with respect to dual fuel dieselbiogas, there is only a $1 \%$ increase in the substitution. The presence of hydrogen in the full load operation increases thermal efficiency, allowing a higher level of substitution.

Figure 6 shows diesel consumption for all operation modes: diesel mode, diesel-biogas dual mode with the highest degree of substitution $(Z=66 \%$ to $8.5 \mathrm{~kW}$, $\mathrm{Z}=58 \%$ to $6 \mathrm{~kW}, \mathrm{Z}=55 \%$ for $4 \mathrm{~kW}$ and $\mathrm{Z}=49 \%$ to 3 $\mathrm{kW}$ ) and diesel-biogas/hydrogen dual mode for the four load levels. The figure also shows the decrease in diesel consumption when engine is working in diesel-biogas dual mode. Additionally, the hydrogen enriched biogas effect -mainly at full load-, presents the best engine operation. For operation at full load, the engine is able to decrease the diesel fuel consumption from $698 \mathrm{~g} / \mathrm{min}$ in diesel mode to $146 \mathrm{~g} / \mathrm{min}$ in diesel-biogas/hydrogen dual mode; which constitutes a $79 \%$ reduction. While for the $50 \%$ load diesel consumption, there are decreases from 445 to $177 \mathrm{~g} / \mathrm{min}$, equivalent to a $60 \%$ reduction.

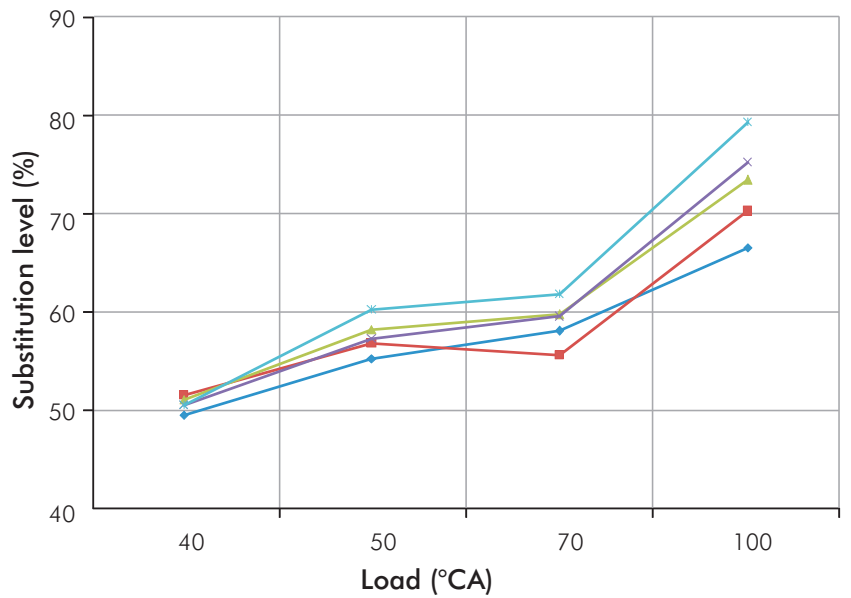

$\rightarrow 0 \% \mathrm{H}_{2} \rightarrow 5 \% \mathrm{H}_{2} \rightarrow-10 \% \mathrm{H}_{2} \rightarrow-15 \% \mathrm{H}_{2} \rightarrow 20 \% \mathrm{H}_{2}$

Figure 5. Variation of the substitution level with engine load and hydrogen enrichment.

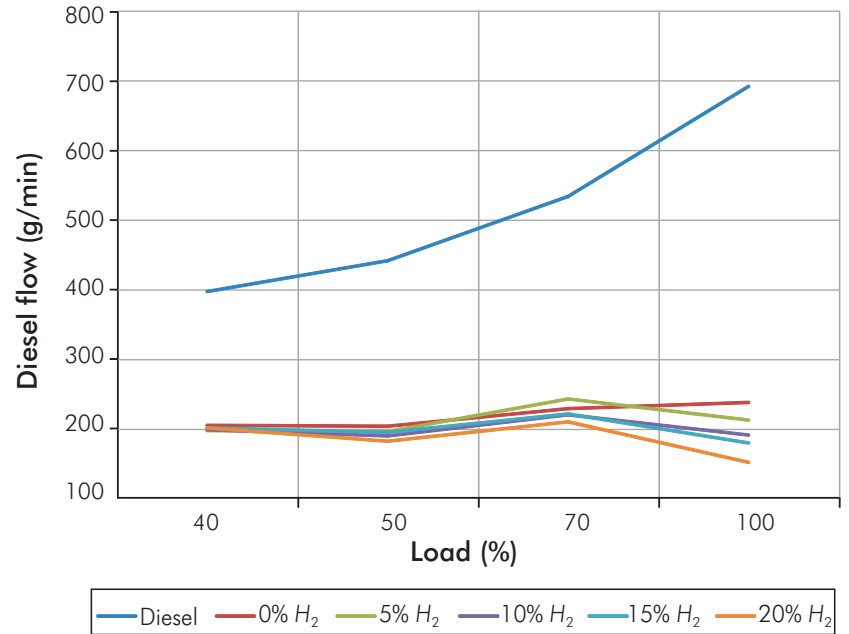

Figure 6. Diesel fuel consumption in diesel, dual diesel biogas, and dual diesel- biogas with hydrogen enrichment.

Figure 7 shows carbon monoxide $(\mathrm{CO})$ emissions variations related to load engine for hydrogen enrichment levels in dual fuel mode. At full load and 20\% of hydrogen addition in the biogas, carbon monoxide emissions decrease by $20 \%$, which is linked to the dieselbiogas dual fuel operation. This occurs due to the presence of $\mathrm{H}_{2}$, allowing the formation of $\mathrm{OH}$ radical, which has a significant kinetic effect for carbon monoxide oxidation by reacting elemental $\mathrm{OH}+\mathrm{CO}-----\mathrm{CO}_{2}+\mathrm{H}$.

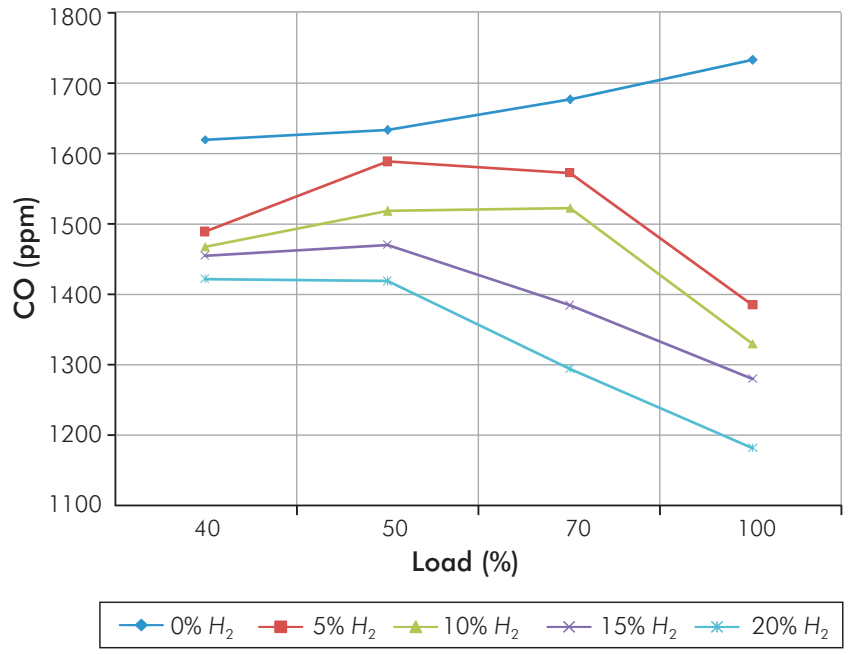

Figure 7. Variation of carbon monoxide (CO) related to hydrogen enrichment for all engine loads in dual mode.

The carbon dioxide emissions were decreased with hydrogen biogas enrichment for all loads such as the ones shown in Figure 8. This is a consequence of the 
replacement of diesel (with high carbon level) by biogas with low level of carbon, and by hydrogen without carbon in its molecular structure.

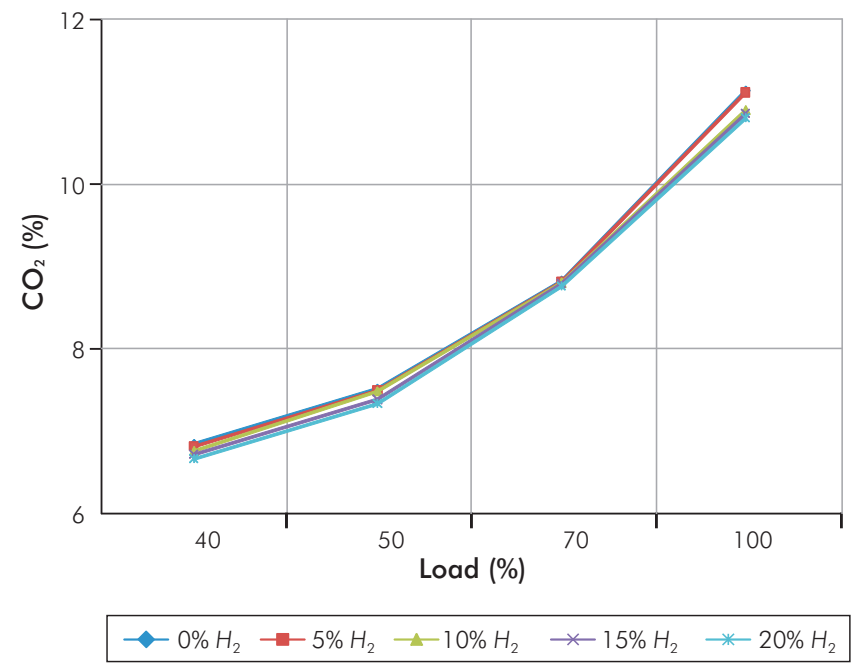

Figure 8. Variation of carbon dioxide emissions $\left(\mathrm{CO}_{2}\right)$ related to engine load with hydrogen enrichment.

Figure 9 shows thermal efficiency for all loads and different hydrogen enriched biogas levels in dual fuel mode diesel-biogas/hydrogen. For the whole load range, the thermal efficiency was increased up to $32.4 \%$ in full load and $20 \% \mathrm{v} / \mathrm{v}$ hydrogen enriched biogas. The improvements on the thermal efficiency are due to an increase in the activity of the partial oxidation reaction -by improving flame fronts propagation from diesel- and to increases in the overall mixture temperatures.

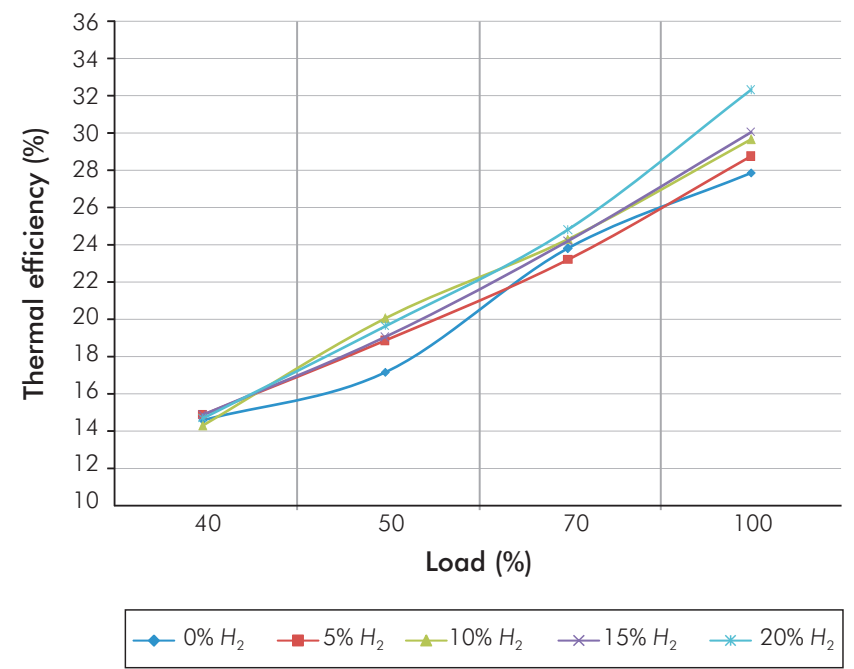

Figure 9. Variation of thermal efficiency with engine load and biogas enriched with hydrogen.
With the addition of hydrogen, the laminar burning velocity increases and the combustion stability improves.

Figure 10 shows the engine used in the experiment, and Figure 11 shows piezoelectric and piezoresistive transducers used to measure the pressure inside the cylinder and in the admission duct.

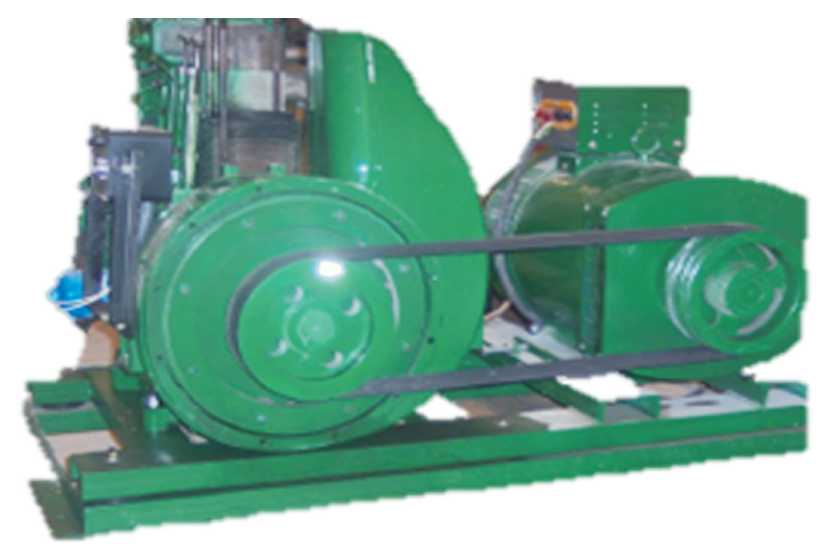

Figure 10. Picture of diesel engine.
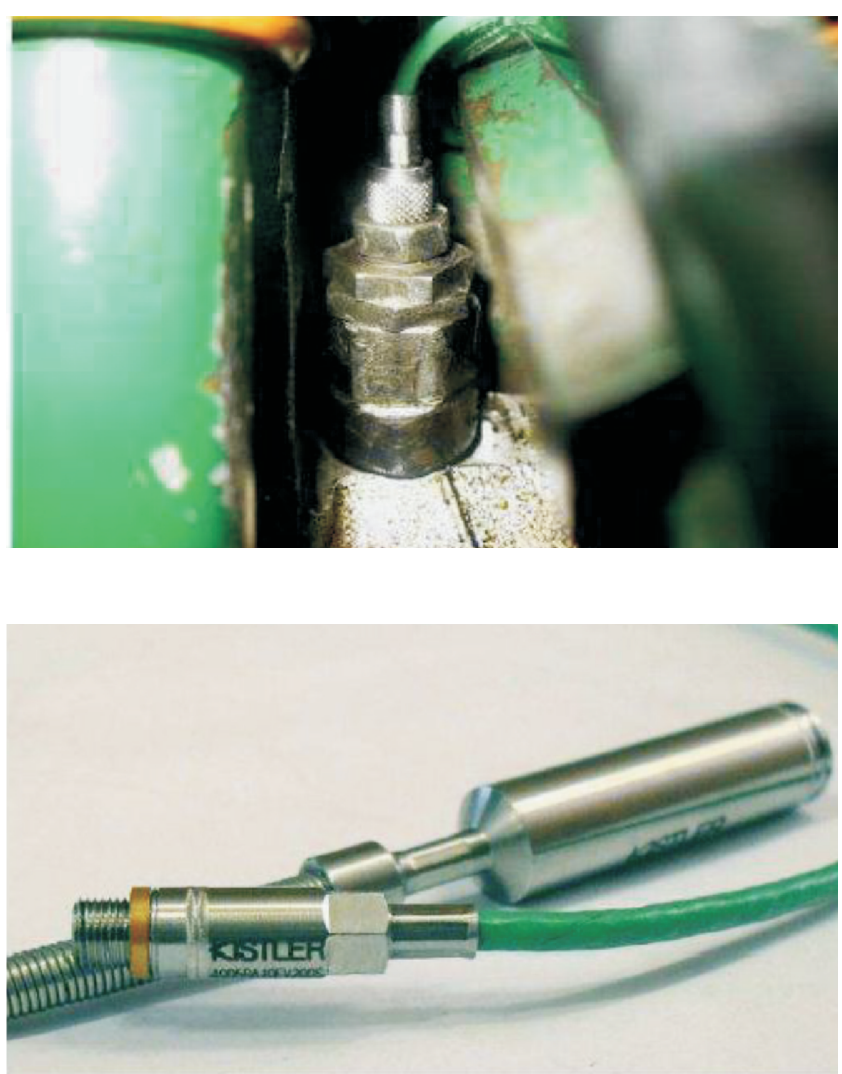

Figure 11. Piezoelectric and piezoresistive transducers. 


\section{CONCLUSION}

In this work, an experimental study was developed to evaluate the effects of hydrogen addition in biogas on a stationary dual fuel engine performance using biogas as primary fuel. The results showed the following:

- The addition of hydrogen to biogas improves the combustion stability and produce increases in the pressure peaks, thermal efficiency and decreases in ignition delay, $\mathrm{CO}$ and $\mathrm{CO}_{2}$ emissions. The effect of hydrogen enriched biogas has a greater influence on cylinder pressure at full load; this increase is about $17 \%$ due to hydrogen enriched biogas from 0 to $20 \%$ by volume, compared with a pressure level increase of about $12 \%$ when the load is $40 \%$.

- The hydrogen enriched biogas (20\% at full load) affects positively $C O$ emissions in a good way, decreasing it up to $30 \%$.

\section{ACKNOWLEDGEMENTS}

Authors are grateful to the Vice-rectory of Investigation and Sustainability, 2011-2012 Program, Universidad de Antioquia, for the financial support of this project.

\section{REFERENCES}

Abd Alla, G., Soliman, H., Badr, O. \& Abd Rabbo, M. (2000). Effect of pilot fuel quantity on the performance of a dual fuel engine. Energy Conversion and Managment, 41(6), 559-572.

Abd Alla, G., Soliman, H, Badr, O. \& Abd Rabbo, M. (2001). Combustion quasi-two zone predictive model for dual fuel engines. Energy Conversion and Managment, 42(12), 1477-1498.

Balasubramanian, V., Sridhara, k. \& Ganesan, V. (1995). Performance evaluation of a small agricultural engine operated on dual fuel (diesel + natural gas) system. $S A E$ Technical Papers, No. 951777.

Bedoya, I., Amell, A., Cadavid, F. \& Pareja, J. (2007). Efecto del grado de carga y la cantidad del combustible piloto en el comportamiento mecánico ambiental de un motor dual diesel-biogás para generación de electricidad. Revista Faculta de Ingeniería Universidad de Antioquia. 42: 79-93.

Bedoya, I., Amell, A. \& Cadavid, F. (2009). Effects of mixing system and pilot fuel quality on diesel-biogas dual fuel engine performance. Bioresour. Technol., 100(24), 6624-6629.

Bilcan, A., Tazerout, M., Le Corre, O. \& Ramesh, A. (2001). Ignition delay in dual-fuel engines: An extended correlation for gaseous fuels. Internal Combustion Engine Division of ASME, Spring Technical Conference, Philadelphia, Pennsylvania, USA.

Duc, P. \& Wattanavichien, K. (2007). Study on biogas premixed charge diesel dual fuelled engine. Energy Conversion and Management, 48(8), 2286-2308.

Henham, A. \& Makkar M. (1998). Combustion of simulated biogas in a dual-fuel, diesel engine. Energy Conversion and Management, 39(16-18), 2001-2009.

Korakianitis, T., Namasivayam, A. \& Crookes, R. (2011). Natural-gas fueled spark-ignition (SI) and compressionignition (CI) engine performance and emissions. Progress in Energy and Combustion Science, 37(1), 89-112.

Lata, D. \& Misra, A. (2010). Theoretical and experimental investigations on the performance of dual fuel diesel engine with hydrogen and LPG as secondary fuels. Int. J. Hydrogen Energy, 35(21), 11918-11931.

Liu, C. \& Karim, G. (2009). Three-dimensional computational fluid simulation of diesel and dual fuel engine combustión. J. Eng. Gas Turbines Power, 131(1), 12804-12812.

Porpatham, E., Ramesh, A. \& Nagalingam, B. (2008). Investigation on the effect of concentration of methane in biogas when used as a fuel for a spark ignition engine. Fuel, 87(8-9), 1651-1659.

Porpatham, E., Ramesh, A. \& Nagalingam, B. (2007). Effect of hydrogen addition on the performance of a biogas fuelled spark ignition engine. Int. J. Hydrogen Energy, 32(12), 2057-2065. 


\section{AUTHORS}

\section{Juan-Pablo Gómez-Montoya}

Affiliation: Grupo de Ciencia y Tecnología del Gas y Uso Racional de la Energía (GASURE), Universidad de Antioquia.

Ing. Mecánica, Universidad de Antioquia.

M. Sc. Ing., Universidad de Antioquia.

e-mail: juan.gomez46@udea.edu.co

\section{Karen-Paola Cacua-Madero}

Affiliation: Universidad de Antioquia.

Ing. Química, Universidad Industrial de Santander.

M. Sc. Ing., Universidad de Antioquia.

e-mail:karen.cacua@udea.edu.co

\section{Layrisser Iral-Galeano}

Affiliation: Grupo de Ciencia y Tecnología del Gas y Uso Racional de la Energía (GASURE), Universidad de Antioquia.

Ing. Mecánica, Universidad de Antioquia.

e-mail: layrisser@udea.edu.co

\section{Andrés-Adolfo Amell-Arrieta}

Affiliation: Grupo de Ciencia y Tecnología del Gas y Uso Racional de la Energía (GASURE), Universidad de Antioquia.

Ing. Mecánica, Universidad de Antioquia.

Magister en Economía de la Energía y los Recursos Naturales, Universidad Nacional de Colombia.

e-mail: anamell@udea.edu.co 


\section{NOTATION}

Z Substitution level

$\eta_{E} \quad$ Thermal Efficiency

$\dot{m}_{b} \quad$ Mass flow in dual fuel mode

$\dot{m}_{b h} \quad$ Biogas-hydrogen mass fuel in dual mode

$\dot{m}_{B} \quad$ Biogas mass flow

$\dot{m}_{h} \quad$ Hydrogen mass flow

$\dot{m}_{D} \quad$ Diesel fuel mass flow

$N_{E} \quad$ Electric power

$P C I_{B} \quad$ Biogas calorific value

$P C I_{h} \quad$ Hydrogen calorific value

$P C I_{D} \quad$ Diesel fuel calorific value 
